\title{
Fodrin Degradation by Calcium-Activated Neutral Proteinase (CANP) in Retinal Ganglion Cell Neurons and Optic Glia: Preferential Localization of CANP Activities in Neurons
}

\author{
Ralph A. Nixon \\ Ralph Lowell Laboratories, Mailman Research Center, McLean Hospital, Belmont, and \\ Department of Psychiatry and Program in Neuroscience, Harvard Medical School, Boston, Massachusetts
}

\begin{abstract}
The activity of calcium-activated neutral proteinases (CANPs) toward endogenous substrates was measured in axons of retinal ganglion cell (RGC) neurons and separately in adjacent optic glia under in vitro conditions that preserved the ultrastructure and anatomic relationships between these cellular elements. RGC neurons and optic glia both expressed CANP activity. In contrast to RGC axons, which contained at least two CANP activities with calcium requirements in the millimolar (CANP A) and micromolar (CANP B) range (Nixon et al., 1985), CANP activity in optic glia was detectable only at millimolar calcium concentrations. When maximally activated, CANP(s) in optic glia exhibited a broad specificity for endogenous proteins but degraded larger proteins at a faster rate. The cytoskeletal protein fodrin (brain spectrin) was among the most susceptible endogenous substrates in RGC axons or glia. The similar properties of fodrin in neurons and glia, including its susceptibility to a purified millimolar calcium-sensitive brain CANP (mCANP), provided the basis for using this protein as a substrate to compare the relative activity of neuronal and glial CANPs in situ. Fodrin degradation mediated by CANPs proceeded at least $6 \times$ more rapidly in intact RGC axons than in optic glia. Comparable differences in the relative degradation rates of the total neuronal and glial protein pools were also observed. These results indicate that the potential activity of CANPs is substantially greater in RGC neurons than in glia. The enormous potential activity and preferential localization of multiple CANP activities in RGC neurons support previously hypothesized roles for CANPs in the processing of axonally transported proteins and in the regulation of neuronal cytoskeletal dynamics and geometry. The markedly different potential activities of CANPs in neurons and glia may have relevance to the greater vulnerability of neurons to degeneration in various neuropathological states.
\end{abstract}

The high affinity of calcium-activated neutral proteinases for certain proteins (Ishiura, 1981; Nixon, 1983; Schlaepfer, 1983) has prompted speculation about their cellular and subcellular localization in nervous tissues and their association with certain organelles. Immunocytochemical studies in non-neural cells provide a basis for suspecting that CANPs may be distributed

Received Nov. 8, 1984; revised Sept. 18, 1985; accepted Sept. 23, 1985.

I am grateful to Dr. Elizabeth Repasky for providing the $\alpha$-spectrin antibody and to Dr. Charles Marotta for performing the two-dimensional gel separations jllustrated in Figure 1. Kimberly Logvinenko, Susan Lewis, and Edward Nichols provided excellent technical assistance. This work was supported by NIH Grants NS1 5494 and NS17535, the Marion Benton Trust, and the Anna and Seymour Gitenstein Foundation. The author was a fellow of the Alfred P. Sloan Foundation.

Correspondence should be addressed to Dr. Nixon, Ralph Lowell Laboratories, McLean Hospital, 115 Mill Street, Belmont, MA 02178.

Copyright (c) 1986 Society for Neuroscience $0270-6474 / 86 / 051264-08 \$ 02.00 / 0$ nonuniformly within cells and among different cell types in the brain. In skeletal muscle cells, for example, the major CANP is highly enriched near the sarcolemma (Barth and Elce, 1981; Dayton and Schollmeyer, 1981) and in the Z-disk region of the myofibril (Dayton and Schollmeyer, 1981). CANP localization in the Z-disk is particularly interesting in view of its exceptional susceptibility to CANP-catalyzed proteolysis (Busch et al., 1972; Reddy et al., 1975), an event that possibly triggers disassembly of the myofibril (Dayton et al., 1981).

At present, few clues exist concerning the localization of CANP forms and CANP activities in the mammalian nervous system. Subcellular fractionation analyses suggest that the major CANP form is a soluble enzyme (Ishiura, 1981), although membranebound CANP activity has also been observed (Baudry et al., 1981). CANP activity has been detected in association with the neurofilament-enriched cytoskeleton (Ishizaki et al., 1983; Pant et al., 1982), a preparation containing proteins that are highly sensitive to CANPs (Banik et al., 1983; Malik et al., 1983; Nixon 1983; Schlaepfer, 1983). Recently, observations that purified myelin fractions contain CANP activity toward myelin basic protein (Banik et al., 1983; Sato and Miyatake, 1983) have raised the possibility that glial cells may also be a site of CANP enrichment. It is unclear in the foregoing studies, however, whether the association of CANP activity with these axonal and glial structures is a physiological property or reflects contamination by the highly active soluble CANPs.

In this study, we measured the relative activity of CANP(s) in axons of retinal ganglion cell (RGC) neurons and in adjacent glial cells to investigate whether CANP(s) distribute nonuniformly among different cells in the brain. By selectively radiolabeling proteins in either RGC axons or glial cells and conducting in vitro studies of proteolysis in excised but otherwise intact optic pathways, CANP activity in glia and axons could be measured while preserving the normal anatomic relationships between these cellular elements (Nixon, 1983; Nixon et al., 1986). The validity and advantages of a cell biological approach to studies of proteolysis are considered further in the accompanying report (Nixon et al., 1986) and elsewhere (Nixon, 1983).

In this investigation of CANP activity, we focused particularly on the degradation of fodrin (Levine and Willard, 1981), a highmolecular-weight cytoskeletal protein that shares properties with spectrin-like proteins in nonneural cells (Glenney et al., 1982b; Goodman and Zagon, 1984). These proteins have generated wide interest as possible regulators of microfilament organization that may potentially govern such microfilament-related functions as cell shape and deformability, cell movement, and membrane protein distribution (Glenney et al., 1982a, b; Siman et al., 1984). In this report, we show that fodrin is present in glia and RGC axons and is among the endogenous proteins most 


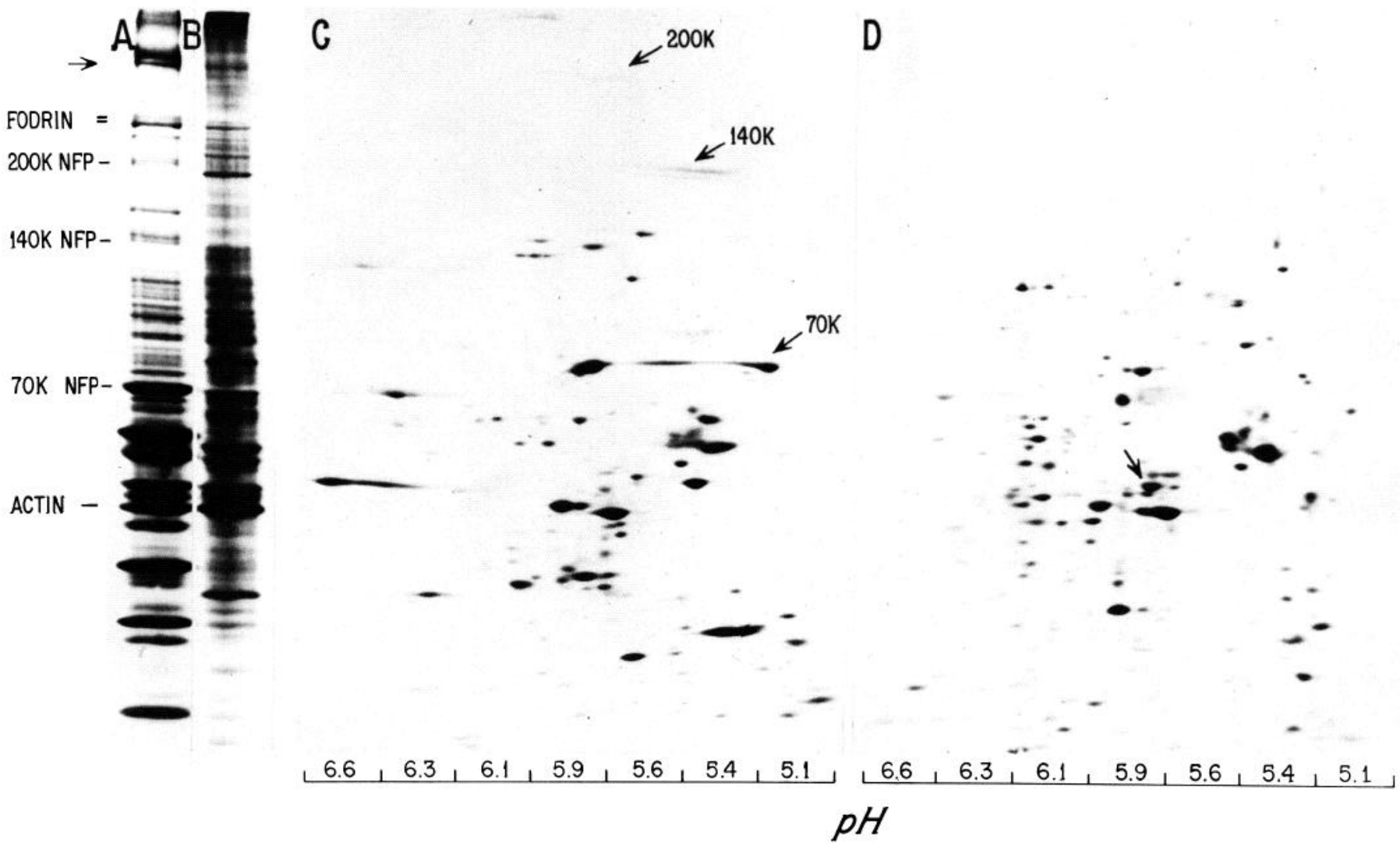

Figure 1. One- and two-dimensional electrophoretic patterns of radiolabeled proteins from RGC axons and from optic nerve glia. RGC axonal proteins were selectively radiolabeled by injecting mice intravitreally with ${ }^{3} \mathrm{H}$-proline or ${ }^{35} \mathrm{~S}$-methionine $6 \mathrm{~d}$ prior to SDS-PAGE analysis, as described in Materials and Methods. Glial proteins were radiolabeled in vitro with the same isotopic amino acids (see Materials and Methods). The one-dimensional gel lanes are fluorograms of $(A){ }^{3} \mathrm{H}$-labeled proteins from RGC axons and $(B){ }^{3} \mathrm{H}$-labeled proteins from optic nerve glial proteins. Proteins of interest are identified. On two-dimensional gels, the three neurofilament protein subunits and glial fibrillary acidic protein $($ arrow $)$ are indicated. The standards used to determine molecular weight values were myosin, 210,$000 ; \beta$-galactosidase, 130,$000 ;$ phosphorylase $b$, 94,000; BSA, 68,000; ovalbumin, 43,000.

sensitive to degradation by CANPs. Since the fodrins synthesized in glia and neurons were equally susceptible to purified brain CANP, we used this protein as a substrate to compare levels of CANP activity in optic glia and RGC neurons in situ.

\section{Materials and Methods}

\section{Selective radiolabeling of proteins in glial cells of the optic nerve in situ}

Procedures for breeding and maintaining adult $\mathrm{C} 57 \mathrm{BL} / 6 \mathrm{~J}$ mice and dissecting optic pathways (optic nerve and optic tract) are described elsewhere (Nixon et al., 1983). The optic pathway specimen is composed of axons but not perikarya of retinal ganglion cell neurons and glial cells (primarily oligodendroglia and astrocytes) and small numbers (less than $1 \%$ ) of fibroblasts and endothelial cells (Tennekoon et al., 1977). Since protein synthesis in axons is negligible (Barondes, 1974), glial proteins could be selectively radiolabeled in vitro.

Optic pathways were incubated at $37^{\circ} \mathrm{C}$ in $0.5 \mathrm{ml}$ of HEPES medium (25 mм HEPES, $5 \mathrm{~mm} \mathrm{KCl}, 110 \mathrm{~mm} \mathrm{NaCl}, 5.0 \mathrm{~mm}$ glucose, adjusted to $\mathrm{pH} 7.4$ with $\mathrm{NaOH}$ ) containing $20 \mu \mathrm{Ci}$ of $\mathrm{L}-4,5-{ }^{3} \mathrm{H}$-leucine (specific activity, $40-60 \mathrm{Ci} / \mathrm{mmol}$ ) or in some cases, $20 \mu \mathrm{Ci}$ of ${ }^{35} \mathrm{~S}$-methionine (specific activity, $400 \mathrm{Ci} / \mathrm{mmol}$ ), or combinations of ${ }^{3} \mathrm{H}$-leucine and $\mathrm{L}-2,3-{ }^{3} \mathrm{H}$-proline $(30-50 \mathrm{Ci} / \mathrm{mmol})$, using $20 \mu \mathrm{Ci}$ of each. After incubating tissue specimens for $50 \mathrm{~min}$, the incubating medium was replaced by $1.0 \mathrm{ml}$ of prewarmed HEPES medium containing the protein synthesis inhibitors cycloheximide $(0.5 \mathrm{~mm})$ and chloramphenicol $(0.3 \mathrm{mg} /$ $\mathrm{ml}$ ) but no radiolabeled amino acid, and the tissue was incubated for 5 $\min$ at $37^{\circ} \mathrm{C}$. The medium was replaced by the same medium, and the incubation was continued for another $5 \mathrm{~min}$ at $37^{\circ} \mathrm{C}$ in order to wash out unincorporated radioactivity. To examine the protein species syn- thesized, radiolabeled optic pathways were subjected to SDS-PAGE and the resulting gels were fluorographed (Nixon et al., 1982).

\section{Analysis of proteolysis in optic nerve glia in situ}

Optic pathways radiolabeled as described above were incubated at $37^{\circ} \mathrm{C}$ in HEPES medium containing $0.3 \mathrm{mg} / \mathrm{ml}$ chloramphenicol and $0.5 \mathrm{~mm}$ cycloheximide, which prevented reutilization of amino acids released by proteolysis (Nixon, 1980). When additions were made to the incubating medium, the tissues were preincubated at $4^{\circ} \mathrm{C}$ for $20 \mathrm{~min}$ in the indicated medium. In some cases, the radiolabeled optic pathways were subjected to two cycles of rapid freeze-thawing to achieve maximal facilitation of calcium ion and enzyme inhibitor entry into the glial cells (Nixon et al., 1986). Incubated optic pathways and unincubated control specimens were subjected to SDS-PAGE on $4-7 \%$ or $5-15 \%$ linear acrylamide gradients (Nixon et al., 1983). In some experiments, the electrophoretically separated proteins stained with Coomassie Brilliant blue were analyzed by cutting $1 \mathrm{~mm}$ sections of an entire gel lane and measuring the radioactivity in each by scintillation counting (Nixon et al., 1986). In other experiments, selected stained protein bands were cut from the gels and similarly analyzed for radioactivity (Nixon et al., 1983). Since the optic pathways were incubated with a constant amount of radioisotope during the initial radiolabeling step, incorporation into protein was similar in each specimen. Degradation was therefore measured as the decrease in the dpm for a given protein in the incubated specimen relative to the $\mathrm{dpm}$ in that protein from an unincubated control optic pathway. In some experiments we employed a protein (protein 23) that is not degraded under any of the conditions used in this study as an internal index of radioactivity incorporated into protein in order to factor out minor variations in radioisotope incorporation among samples. In these experiments, the radioactivity in a given protein from 


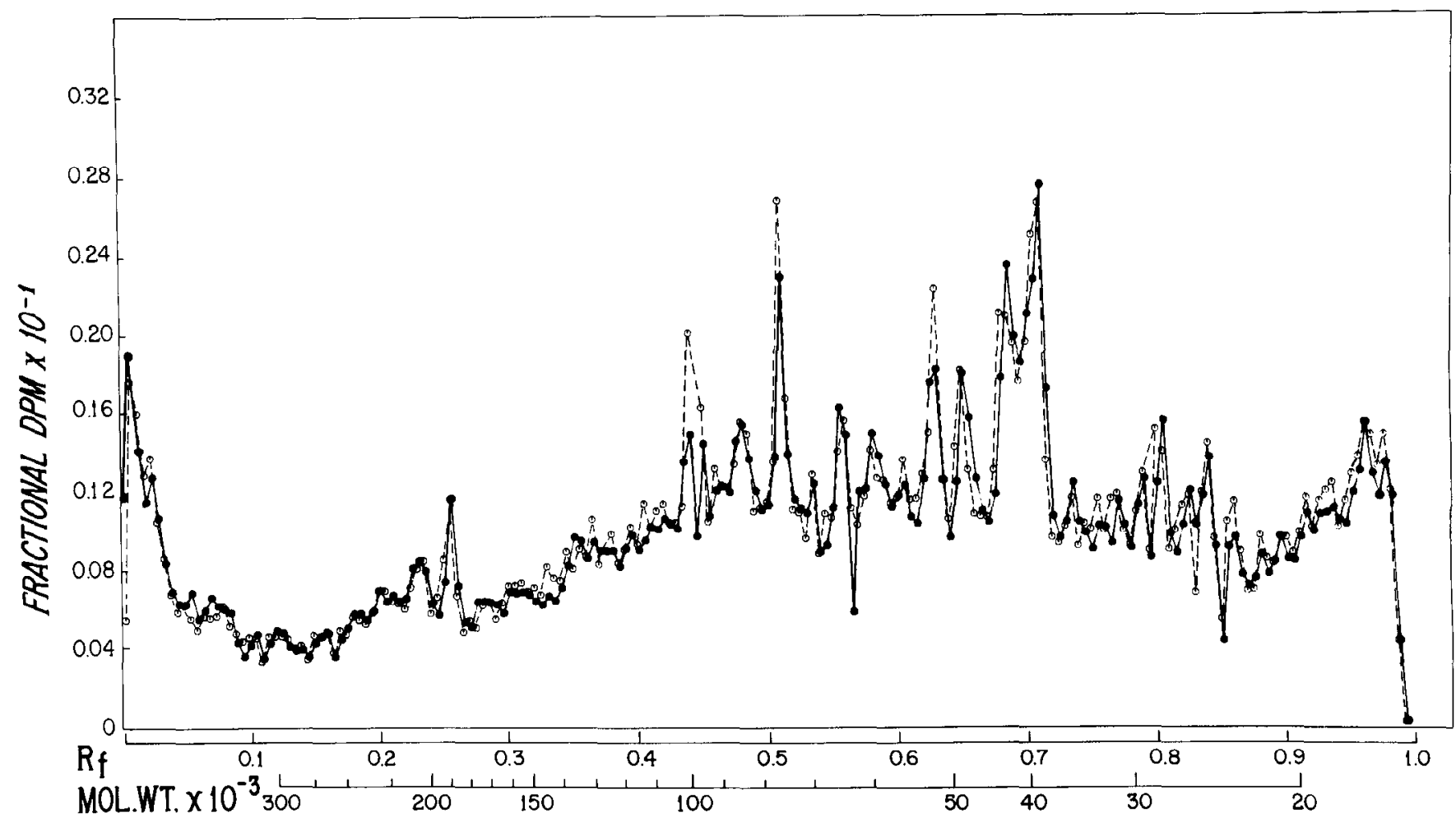

Figure 2. Specificity of glial CANPs for proteins in glia of freshly dissected optic nerves. Glial proteins were selectively labeled with ${ }^{3} \mathrm{H}$-proline in vitro. The optic nerves were incubated for $90 \mathrm{~min}$ at $37^{\circ} \mathrm{C}$ in HEPES medium containing $5 \mathrm{~mm} \mathrm{EGTA}(-\rightarrow)$ or $4 \mathrm{~mm} \mathrm{CaCl}(--0--)$. After SDS-PAGE, the electrophoretic patterns were established from the radioactivity in consecutive $1 \mathrm{~mm}$ slices of each gel lane. The radioactivity of each gel slice is expressed as a percentage of the total radioactivity associated with proteins on the gel, referred to as fractional dpm (Nixon et al., 1986). The total protein radioactivity in a typical gel was 300,000-800,000 dpm. Comparison of these tracings demonstrates the negligible activity of CANPs under these conditions. An apparent difference in the electrophoretic patterns of $R_{f}=0.45$ is a gel-slicing artifact.

incubated and nonincubated samples was expressed as a fraction of the radioactivity in protein 23 bcfore calculating the extent of degradation. This procedure was therefore used in the studies of proteolysis inhibitors to permit effects of certain inhibitors to be quantitated more sensitively.

\section{Proteolysis in $R G C$ axons in situ}

Proteins in RGC axons were labeled by intravitreal injection of mice with $15 \mu \mathrm{Ci}$ of $\mathrm{L}-2,3-{ }^{3} \mathrm{H}$-proline or $25 \mu \mathrm{Ci}$ of ${ }^{35} \mathrm{~S}$-methionine (Nixon, 1980; Nixon et al., 1986). Proteolysis of specific axonal proteins was measured as described in the accompanying report (Nixon et al., 1986).

\section{Phosphorylation of glial and axonal proteins}

To phosphorylate axonal proteins, mice were injected intravitreally with $50-100 \mu \mathrm{Ci}$ of ${ }^{32} \mathrm{P}$ inorganic phosphate as the tripotassium salt (specific activity, $1000 \mathrm{Ci} / \mathrm{mmol}$ ). Optic pathways were analyzed by SDS-PAGE, $3 \mathrm{~d}$ after injection. Proteins in glial cells were phosphorylated by incubating optic pathways in HEPES medium containing $50 \mu \mathrm{Ci}$ of tripotassium ${ }^{32} \mathrm{P}$-phosphate for $60 \mathrm{~min}$ at $37^{\circ} \mathrm{C}$. After SDS-PAGE, ${ }^{32} \mathrm{P}$ labeled axonal or glial proteins were visualized by autoradiography.

\section{Immunostaining of proteins}

Polyclonal antibody to erythrocyte $\alpha$-spectrin (Repasky et al., 1982) was generously provided by Dr. Elizabeth Repasky. PAGE-separated proteins of the mouse optic pathway were electrophoretically transferred to nitrocellulose membranes. The membrane-bound proteins were immunostained with antiserum to $\alpha$-spectrin by means of a HRP-conjugated indirect antibody procedure as described in Brown et al. (1983a).

Digestion of radiolabeled axonal and glial cytoskeletal proteins by purified mouse brain CANP

Proteins in optic nerve glial cells were radiolabeled with $\mathrm{L}-{ }^{14} \mathrm{C}(\mathrm{U})$-proline (specific activity, $225 \mathrm{mCi} / \mathrm{mmol}$, New England Nuclear, Cambridge, $\mathrm{MA}, 10 \mu \mathrm{Ci}$ per pathway) and $\mathrm{RGC}$ axonal proteins with ${ }^{3} \mathrm{H}$-proline, using the procedures described above. Cytoskeletal protein fractions were prepared by the method of Chiu and Norton (1982) from groups of optic pathways containing ${ }^{14} \mathrm{C}$-labeled glial proteins or ${ }^{3} \mathrm{H}$-labeled axonal proteins. An amount of each fraction was combined in a $1: 2$ proportion of axonal-to-glial-labeled protein to achieve the appropriate ratio of ${ }^{3} \mathrm{H}$ to ${ }^{14} \mathrm{C} \mathrm{dpm}$ (10-15:1). A portion of the mixture was then incubated with mCANP purified from mouse brain (Nixon et al., 1986) at $32^{\circ} \mathrm{C}$ in $0.05 \mathrm{M}$ Tris buffer, $\mathrm{pH} 7.2$, containing $2 \mathrm{~mm}$ dithiothreitol and either $15 \mathrm{~mm} \mathrm{CaCl}_{2}$ or $5 \mathrm{~mm}$ EGTA. A ratio of enzyme activity to substrate was chosen that, during a $15 \mathrm{~min}$ incubation, produced degradation of $30-50 \%$ of the $\alpha$ - and $\beta$-fodrin subunits (see Results). Samples incubated for $0-15 \mathrm{~min}$ were each subjected to SDS-PAGE, and the bands corresponding to the fodrin doublet were excised from the gel. The samples were counted in a Beckman LS- 7000 counter equipped with external standard and automatic quench correction modes. Selected samples were recounted after the addition of an aliquot of ${ }^{3} \mathrm{II}$-toluene or ${ }^{14} \mathrm{C}$-toluene to determine efficiencies and isotope crossover. Tritium efficiency was $55 \%$, and ${ }^{14} \mathrm{C}$ efficiency, $75 \%$. The ${ }^{14} \mathrm{C}$-to- ${ }^{3} \mathrm{H}$ crossover averaged $20 \%$, and the ${ }^{3} \mathrm{H}-10-{ }^{-14} \mathrm{C}$ crossover, $0.85 \%$. These values from different samples of the same gel did not vary significantly.

\section{Results}

\section{Radiolabeled proteins of glial cells and $R G C$ axons}

Optic pathways retained their normal ultrastructure under the conditions employed to radiolabel glial proteins in vitro and subsequently to analyze proteolysis (Nixon et al., 1986). The electrophoretic pattern of ${ }^{35} \mathrm{~S}$-methionine-labeled glial proteins differed qualitatively and quantitatively from the pattern of radiolabeled proteins in RGC axons from mice injected intravitreally with the same amino acid (Fig. 1). Certain heavily labeled glial proteins were not observed in RGC axons containing radiolabeled proteins in the slowest phases of axoplasmic trans- 


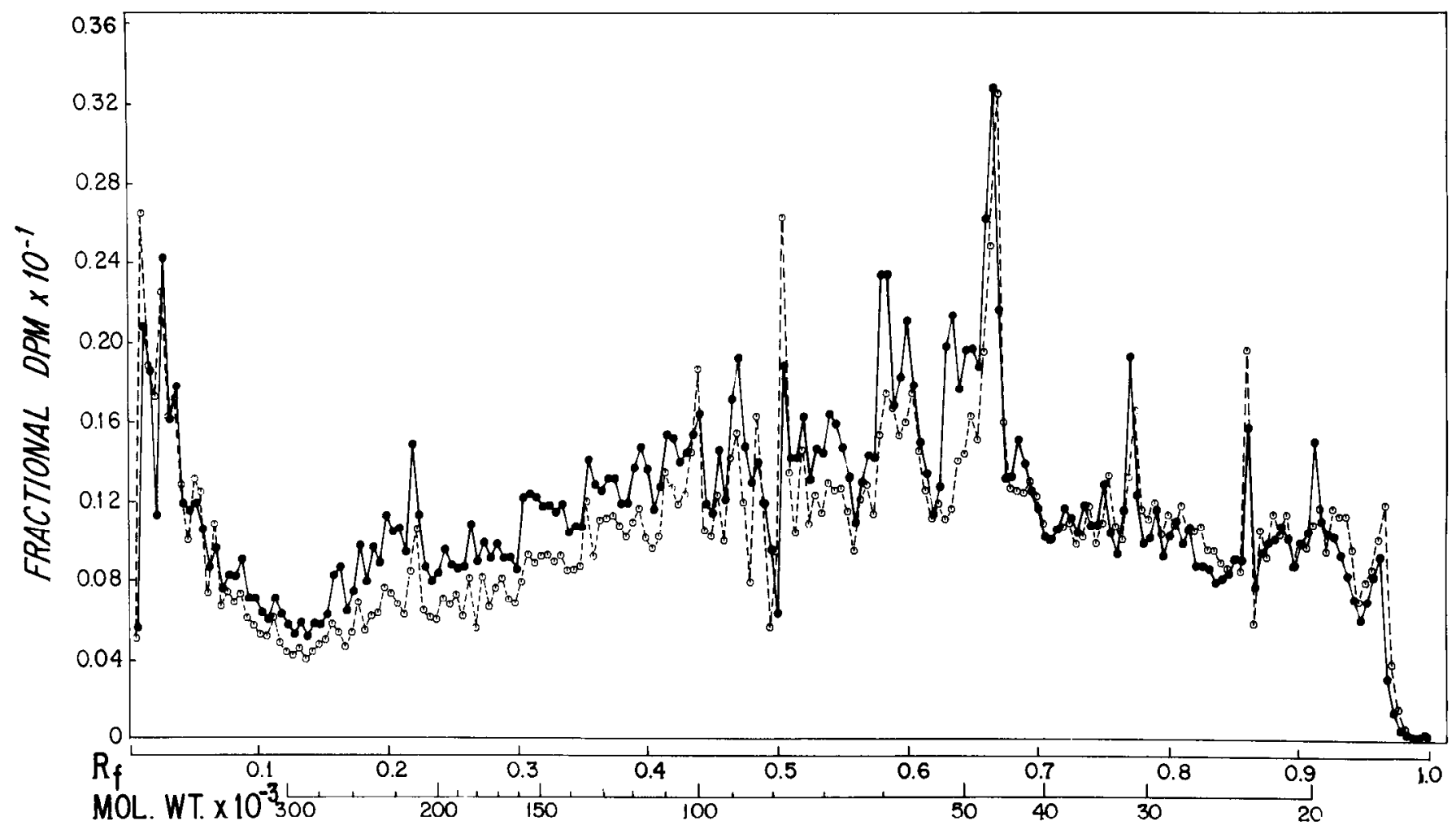

Figure 3. Specificity of glial CANPs for proteins in optic glial cells. Optic nerves containing selectively radiolabeled glial cells were quick-frozen and thawed twice before incubation to activate CANPs maximally. Tracings illustrate the electrophoretic patterns of radiolabeled glial proteins after radiolabeled optic nerves were incubated for $30 \mathrm{~min}$ at $37^{\circ} \mathrm{C}$ in HEPES medium containing $5 \mathrm{~mm}$ EGTA $(\rightarrow-)$ or $4 \mathrm{~mm} \mathrm{CaCl}(--O--)$. Differences between these two tracings reflect the activity of CANPs requiring millimolar calcium concentrations added to the incubating medium for maximal activity.

port (Group V and Group IV; Fig. 1) or in other transport phases (Groups I-II, 6-24 hr postinjection; not shown). Among the glia-specific groups was a protein tentatively identified as glial fibrillary acidic protein (GFAP) by its migration on one- and two-dimensional gels, enrichment in preparations of cytoskeletal proteins, and cross-reactivity with antibody to bovine GFAP (Brown et al., 1981). By contrast, neuron-specific proteins, such as the neurofilament protcin triad, wcre radiolabclcd in axons but not in glia. Other radiolabeled proteins, which were present in glial cells and in neurons, provided the basis for comparing CANP activities in these different cell types (see below).

\section{Calcium-stimulated loss of glial proteins in situ}

Optic pathways containing radiolabeled glial proteins were incubated for $2 \mathrm{hr}$ at $\mathrm{pH} 7.4$ in HEPES medium containing $4 \mathrm{~mm}$ $\mathrm{CaCl}_{2}, 10 \mathrm{~mm}$ EGTA, or no additions. The incubated optic pathways were subjected to SDS-PAGE, and radioactivity was measured in consecutive $1 \mathrm{~mm}$ segments of each gel lane. Numerous radioactivity peaks corresponding to the protein bands in Figure 1 were observed in tissues incubated with EGTA ("control" pathways; Fig. 2). In optic pathways incubated for $90 \mathrm{~min}$ without added calcium, the quantitative pattern of radiolabeled glial proteins was identical to that in samples incubated in the presence of EGTA (data not shown).

When fresh optic pathways were incubated in medium containing $4 \mathrm{mM} \mathrm{CaCl}_{2}$ to activate CANPs, only a few high-molecular-weight proteins possibly exhibited lower levels of radioactivity compared to samples incubated with EGTA (Fig. 1). If intracellular transport of exogenous calcium was facilitated by adding calcium ionophore A23187 to the incubating medium, a slightly increased loss of these high-molecular-weight proteins occurred (see Table 1). Raising calcium levels further by rapidly freezing and thawing the optic pathways before incubation with $4 \mathrm{mM} \mathrm{CaCl}_{2}$ yielded a substantially higher rate of disappearance of glial proteins (Fig. 3). Calcium-mediated degradation was most rapid for high-molecular-weight proteins, although a substantial amount of radioactivity that migrated diffusely near the top of the gel (also Fig. $1 B$ ) was not appreciably degraded. Under conditions of maximal CANP activation, about $0.5 \%$ of the total protcin in control pathways was lost from gels during a $30 \mathrm{~min}$ incubation.

When the release of acid-soluble radioactivity from proteins rather than the loss of specific proteins was measured as an index of proteolysis, a slow rate of calcium-stimulated proteolysis could be detected by incubating fresh optic pathways $(0.15 \pm$ $0.08 \%$ per hr, $n=7$ ). Under conditions of maximal CANP activation (freeze-thawed samples; $4 \mathrm{~mm} \mathrm{CaCl}$ ), $0.58 \%$ ( $\mathrm{SEM} \pm$ $0.15, n=9$ ) of the total radioactivity in protein was released in a 30 min incubation. The calcium-mediated hydrolysis of proteins was completely inhibited by sulfhydryl reagents ( $N$-ethylmaleimide, iodoacetate, or mersalyl at $2 \mathrm{~mm}$ ) and was optimal in the $\mathrm{pH}$ range of 7.0-8.5.

\section{Suitability of fodrin as a substrate for axonal and glial CANPs}

To compare the relative CANP activity in glial cells and RGC axons, it was necessary to identify a substrate that exists in both locations and is structurally identical at each site. A protein doublet with molecular weights of 235 and $240 \mathrm{kDa}$, respectively, exhibited these characteristics. The $240 \mathrm{kDa}$ protein crossreacted with polyclonal antibody against the $\alpha$ subunit of mouse erythrocyte spectrin (Koenig and Repasky, 1985; see Fig. 4) and the doublet exhibited properties consistent with its identification as the $\alpha$ and $\beta$ subunits of fodrin (Goodman and Zagon, 1984; 
Levine and Willard, 1981). For example, the doublet was highly radioactive in preparations of radiolabeled optic nerve glia or RGC axons (Fig. 1). A fraction of each protein was transported in vivo at a rate of $20-30 \mathrm{~mm} / \mathrm{d}$ (Group II), although additional amounts were also transported in Groups IV (SCb) and V (SCa) of axoplasmic transport (R. A. Nixon, unpublished observations). Optic pathways from mice injected intravitreally with ${ }^{32} \mathrm{P}$-orthophosphate or optic pathways incubated in vitro with ${ }^{32} \mathrm{P}$-orthophosphate contained a highly phosphorylated protein corresponding in molecular weight to the $\beta$ subunit of fodrin (Goodman et al., 1984; see Fig. 5). The specific phosphorylation of glial proteins in vitro was suggested by the absence of significant radiolabeling of neurofilament proteins and other neuronspecific phosphoproteins (Nixon et al., 1985a) under conditions in which several major glial proteins, tentatively identified as GFAP and myelin basic protein (Murray and Steck, 1984), were labeled. Finally, more than $90 \%$ of the fodrin from either glia or RGC axons, labeled with ${ }^{32} \mathrm{P}$-orthophosphate (Fig. 5) or ${ }^{35} \mathrm{~S}$ methionine (not shown), was associated with the Triton X-100 insoluble fraction of cytoskeletal proteins.

If fodrin were structurally identical in glial cells and RGC axons, the susceptibility of the substrate from each source to purified CANP should be the same. To test this possibility, cytoskeletal protein fractions were prepared from optic pathways containing ${ }^{14} \mathrm{C}$-proline-labeled glial proteins or ${ }^{3} \mathrm{H}$-prolinelabeled RGC axonal proteins, and mixtures of the two differentially labeled fractions were exposed to purified mouse brain mCANP (Nixon et al., 1986) for varying intervals of time. The ${ }^{14} \mathrm{C} /{ }^{3} \mathrm{H}$ ratio in fodrin before incubation $(0.31 \pm 0.04, n=4)$ remained constant when approximately $10 \%(0.29 \pm 0.02, n=$ 4) or $50 \%(0.33 \pm 0.04, n=4)$ of the total protein in the fraction was digested, indicating that glial and axonal forms of fodrin were degraded at the same rate by mCANP.

\section{CANP activity toward fodrin in glial cells and}

\section{$R G C$ axons in situ}

The loss of radiolabeled fodrin from glial cells required calcium ion in the incubating medium. No appreciable loss of glial fodrin occurred in the presence of EGTA $(5 \mathrm{~mm})$ or at endogenous levels of calcium, even when the release of endogenous calcium stores was facilitated with ionophore A23187 or by freezing and thawing the optic pathways before incubation. The rate of fodrin loss was maximal in frozen-thawed optic pathways at calcium concentrations of $4 \mathrm{~mm}$ or higher. Under these conditions, the effects of enzyme inhibitors on the calcium-stimulated loss of fodrin in glial cells and in RGC axons were similar (Nixon et al., 1986). Fodrin degradation was completely inhibited by sulfhydryl reagents, including iodoacetate $(2 \mathrm{mM})$ and mersalyl ( $5 \mathrm{~mm})$. Substantial inhibition ( $77 \%$, glia; $85 \%$, axons) was also observed with leupeptin $(200 \mu \mathrm{g} / \mathrm{ml})$. In contrast, phenylmethylsulfonyl fluoride had no apparent effect.

Since calcium-dependent loss of high-molecular-weight proteins in glia and axons seemed to involve a CANP optimally active at millimolar calcium levels, and purified brain mCANP degraded axonal and glial fodrin at the same rate, we employed fodrin as a substrate to measure the relative activity of CANP in these two cellular sites(Table 1). CANP activity toward fodrin was substantially higher in RGC axons than in adjacent glia at various levels of activation of the enzyme by calcium. A substantial CANP-mediated loss of fodrin in RGC axons $\left(t_{1 / 2}=5.8\right.$ hr) was observed when freshly dissected optic pathways were incubated in medium containing $4 \mathrm{~mm}$ calcium. Under the same conditions, CANP activity toward fodrin in glia was below the level of detection during a 90 min incubation (Table 1).

Adding ionophore A23187 to the incubating medium stimulated CANP at both cellular sites; however, CANP activity remained at least $5 \times$ higher in axons than in glia. Maximal activation of CANPs by freezing and thawing optic pathways

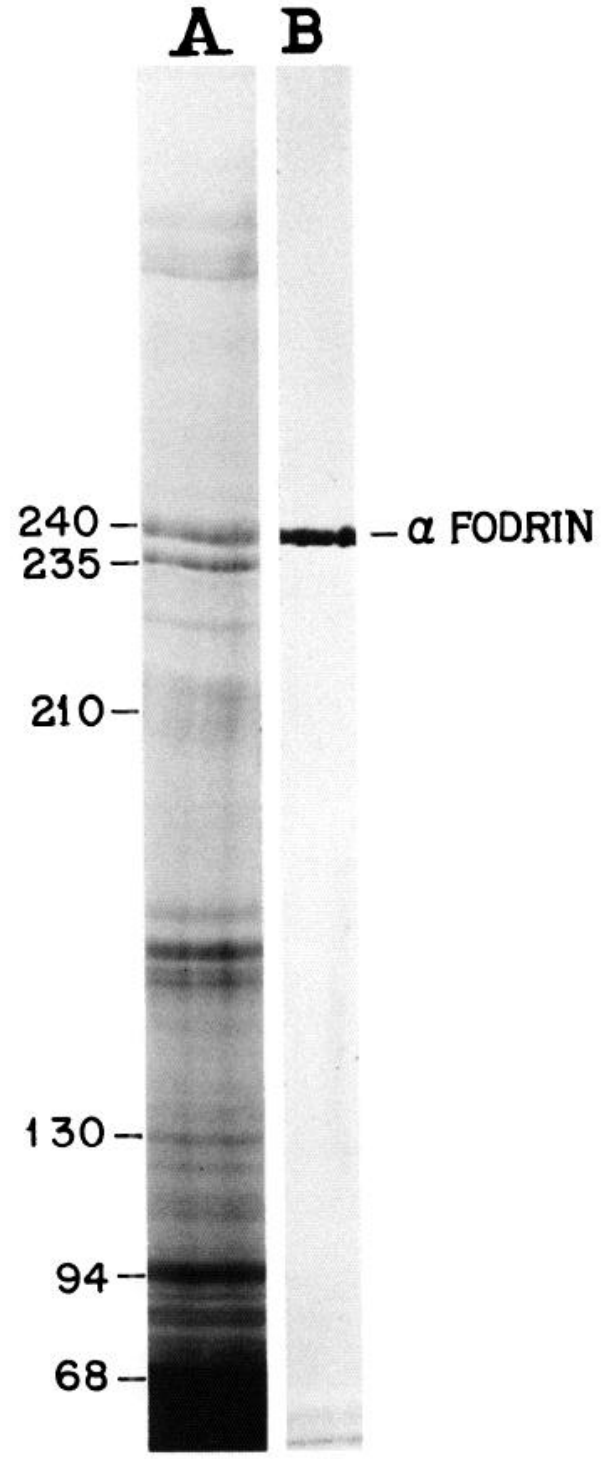

Figure 4. Immunostaining of $\alpha$-fodrin with antiserum to erythrocyte $\alpha$-spectrin. Optic pathway proteins separated by SDS-PAGE $(4-7 \%$ acrylamide gradient) were stained with Coomassie Brilliant blue $(A)$ or electrotransferred to nitrocellulose and immunostained with $\alpha$-spectrin antibodies by the HRP-conjugated double-antibody method $(B)$. A single band with a molecular weight of $240 \mathrm{kDa}$, corresponding to the size of the $\alpha$ subunit of fodrin, was selectively immunostained. Molecular weights of standard proteins are indicated (see Fig. 1).

twice before incubation led to extensive fodrin degradation at a constant logarithmic rate (Fig. 6). CANPs in intact axons degraded $50 \%$ of the radiolabeled pool of axonal fodrin in less than $8 \mathrm{~min}$. By comparison, fodrin degradation in glial cells was at least $10 \times$ slower $\left(t_{1 / 2}=90 \mathrm{~min}\right.$; Table 1$)$.

\section{Discussion}

The negligible level of protein synthesis in isolated axons (Barondes, 1974) enabled us to selectively radiolabel proteins in glial cells of the optic pathway in vitro. Selectivity was evident from the intense radiolabeling of certain proteins that are specifically associated with the major glial cell types composing optic nerve (Dahl and Bignami, 1973). By contrast, in optic pathways from mice injected intravitreally in vivo, these proteins remained unlabeled, while neuron-specific proteins, including the neurofilament triad, were highly radioactive. Nonglial cell 


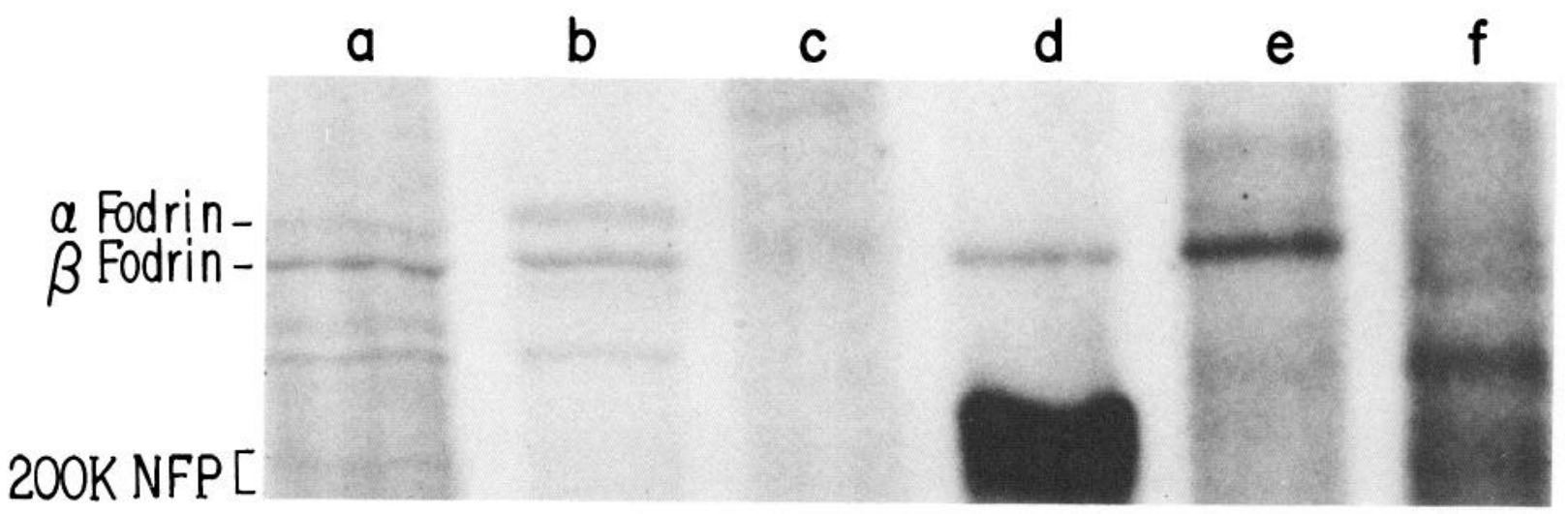

Figure 5. Properties of fodrin in RGC axons and optic nerve glia. Glial or RGC axonal proteins were selectively radiolabeled with either ${ }^{35}$ Smethionine or ${ }^{32} \mathrm{P}$-orthophosphate, as described in Materials and Methods. Optic pathways containing ${ }^{32} \mathrm{P}-$ labeled glial or axonal proteins were separated into Triton X-100 soluble and insoluble fractions (Chiu and Norton, 1982). Samples were subjected to SDS-PAGE (4-7\% acrylamide gradient) and autoradiography. Only the gel regions between 180 and $300 \mathrm{kDa}$ are presented for each condition, which includes total ${ }^{35} \mathrm{~S}-\mathrm{labeled}$ glial proteins $(a)$; radiolabeled RGC axonal proteins $6 \mathrm{~d}$ after intravitreal injection of ${ }^{35} \mathrm{~S}$-methionine $(b)$; ${ }^{32} \mathrm{P}$-labeled axonal proteins - Triton X-100 soluble fraction $(c)$ and insoluble fraction $(d)$; and ${ }^{32} \mathrm{P}$-labeled glial proteins-Triton X-100 insoluble fraction $(e)$ and soluble fraction $(f)$.

types are a very small proportion of the optic nerve (Tennekoon et al., 1977) and presumably incorporate a minor amount of radioactivity. By preserving the ultrastructure of the optic pathways during incubation in vitro, it has been possible to study the proteolysis of endogenous proteins by specific proteinases in axons or glia without physically disrupting the normal anatomic relationships between these cellular elements. Since most procedures for isolating neurons and glia involve the use of exogenous proteolytic enzymes to dissociate the cells before separation, eliminating this complicating variable is particularly advantageous in studies of proteolysis.

Our studies indicate that calcium-activated neutral proteinase is present in glial cells and exhibits properties characteristic of the major mCANP(s) from other tissue sources (Ishiura, 1981; Malik et al., 1983; Murachi, 1983; Nixon et al., 1986; Zimmerman and Schlaepfer, 1984), including optimal activation by millimolar calcium levels, sulfhydryl dependence, leupeptin sensitivity, and relatively broad susbstrate specificity. Although CANP activity toward glial proteins was low, several observations indicated that the enzyme involved resides in glial cells and is not an axonal contaminant. CANP-mediated proteolysis was observed in freshly dissected optic pathways when a sensitive assay based on the release of acid-soluble radioactivity from the total pool of radiolabeled glial proteins was used. In addition, CANP-mediated proteolysis of individual proteins in glial cells was stimulated by calcium ionophore A23187 under conditions that preserved the membrane integrity of cellular elements in the optic pathway. Finally, preliminary experiments indicate that, although CANPs exhibit proximodistal variations in activity along the optic pathway, the distribution of glial CANP activity is uniform (R. A. Nixon, unpublished observations).

Fodrin was among the most susceptible endogenous substrates of CANP. This cytoskeletal protein is concentrated in the cortical cytoplasm of neurons and glia (Levine and Willard, 1981; Zagon et al., 1984) and exhibits structural and functional similarities to spectrin (Glenney et al., 1982b; Goodman and Zagon, 1984), which is also highly susceptible to CANPs (Siman et al., 1984). Fodrin synthesized in mouse optic glia or RGC neurons resembled its counterpart from other neural sources (Goodman and Zagon, 1984) with respect to subunit size (Goodman et al., 1984; Levine and Willard, 1981), immunoreactivity with erythroid $\alpha$-spectrin antibodies (Koenig and Repasky, 1985; Repasky et al., 1982), enrichment in cytoskeleton preparations, and movement in multiple phases of axoplasmic transportGroups II, IV, and V in the rabbit visual system (Levine and Willard, 1981). Like spectrin (O'Connell and Swislocki, 1983) and spectrin-like proteins (Goodman and Zagon, 1984), fodrin appears to be a phosphoprotein. In both glial cells and axons, only the $235 \mathrm{kDa}$ fodrin subunit was intensely phosphorylated, as recently observed by others using a different in vivo approach (Goodman et al., 1984).

On the basis of relative rates of fodrin degradation, we have shown that the potential activity of CANP is substantially

\section{Table 1. Relative rates of fodrin degradation by CANPs in RGC axons and optic glia}

Fodrin half-life

\begin{tabular}{lllc}
\cline { 2 - 4 } Additions to the incubating medium & RGC axons & Optic glia & $\begin{array}{l}\text { Axons/ } \\
\text { glia }\end{array}$ \\
\hline EGTA, $5 \mathrm{~mm}$ & $\mathrm{ND}^{a}$ & $\mathrm{ND}$ & - \\
$\mathrm{CaCl}_{2}, 4 \mathrm{mM}$ & $5.80 \pm 0.38$ & $\mathrm{ND}$ & - \\
Ionophore A23187, $4 \mathrm{mM} \mathrm{CaCl}_{2}$ & $1.39 \pm 0.10$ & $8.20 \pm 0.21$ & 5.9 \\
Frozen-thawed tissues, $4 \mathrm{mM} \mathrm{CaCl}_{2}$ & $0.13 \pm 0.02$ & $1.55 \pm 0.20$ & 11.9
\end{tabular}

Optic pathways containing selectively radiolabeled axonal or glial proteins (see text) were incubated at $37^{\circ} \mathrm{C}$ for varying intervals from 0 to $60 \mathrm{~min}$ in HEPES medium containing the indicated additions. After subjecting the tissues to SDSPAGE, the half-life of fodrin was calculated by quantitating the time-dependent loss of radioactive fodrin as in Figure 6 . Each value is the mean \pm SEM for four to seven determinations.

a Not detectable degradation. 


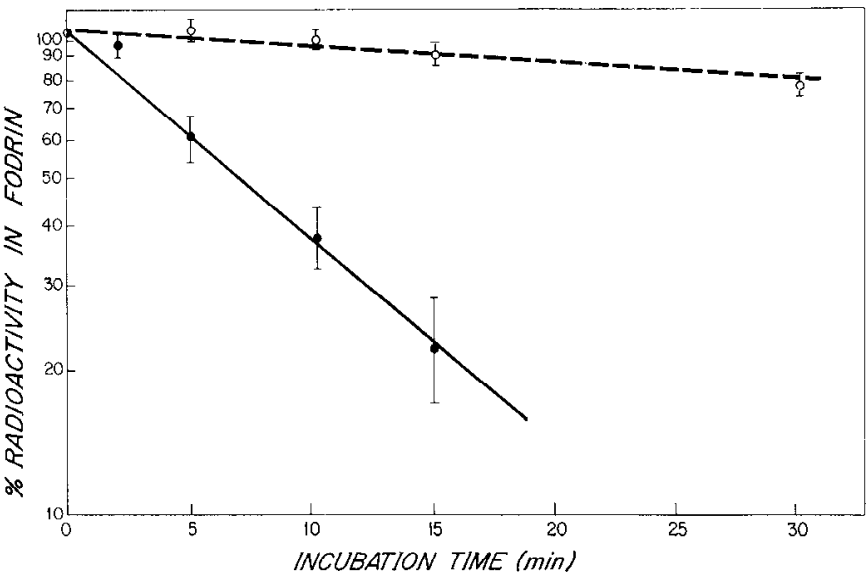

Figure 6. Comparison of the rates of fodrin degradation by CANP in RGC axons and optic nerve glia. Optic pathways in which either RGC axons (-) or optic glia (--O--) were selectively radiolabeled with ${ }^{3} \mathrm{H}$-proline were incubated for varying time intervals in HEPES medium containing $4 \mathrm{mM} \mathrm{CaCl}_{2}$. The optic pathways were rapidly frozen and thawed twice before incubation to maximally activate CANP. After SDS-PAGE, the radioactivity of fodrin in each sample was determined. Each value is the mean and SEM (error bars) for four determinations. No degradation of axonal or glial fodrin was detectable in the absence of added calcium.

greater in RGC axons than in neighboring glial cclls. Certain factors that might artifactually contribute to such differences were controlled in these studies. For example, CANPs were measured at various levels of activation by calcium to reduce the possibility that the results might reflect differential calcium penetration into axons and glia. Although neuronal and glial forms of fodrin were examined at different intervals after radiolabeling, the studies of fodrin digestion by purified brain mCANP indicated that, if glial and axonal fodrins differ structurally, the differences do not influence susceptibility to proteolysis. Furthcrmore, the behavior of CANPs toward other glial proteins also supports the notion that CANP activity is higher in RGC axons than in glial cells. A second protein synthesized in neurons and glia (Fig. $1 D$, arrow) exhibited differential rates of degradation similar to those of fodrin (R. A. Nixon, unpublished observations). Although the composition of the total radiolabeled protein pools in axons and glia differed, the average degradative rate for the axonal pool was also at least $10 \times$ faster than that in glia when CANPs were maximally activated. These results, in turn, are consistent with preliminary immunocytochemical observations that neurons contain more immunoreactive CANP than glial cells (R. A. Nixon, unpublished observations).

The absence of CANP activity toward major radiolabeled glial proteins at endogenous calcium levels suggests that glial cells may also lack a micromolar-calcium-sensitive CANP ( $\mu$ CANP) comparable to the form present in RGC neurons (CANP B), which selectively cleaves the $145 \mathrm{kDa}$ neurofilament protein subunit (Nixon et al., 1986). $\mu$ CANPs have been isolated previously from brain tissue (Kishimoto, 1981; Malik et al., 1983; Zimmerman and Schlaepfer, 1984), and a $\mu$ CANP with selectivity for intermediate filament proteins has been isolated from non-neural tissue (Nelson and Traub, 1982). If $\mu$ CANP were present in glial cells, however, its activity toward major glial proteins was below the limit of detection or was inhibited under conditions that allow CANP A activity in neurons to be expressed. In addition, we found no evidence that glial fibrillary acidic protein, the intermediate filament protein of astrocytes, was selectively degraded or modified. In sum, our findings therefore provide initial evidence for the preferential localization in neurons of at least two CANP activities, CANP A and CANP $B$ (Nixon et al., 1986).

The high content of CANPs in neurons provides a basis for several suspected roles for these enzymes. The disappearance of some transported proteins as they approach or enter axon terminals suggests that proteolysis, including CANP-mediated events (Roots, 1983; Sandberg et al., 1980), may be active in synaptic terminals (Lasek and Hoffman, 1976). A portion of the CANP in axons may therefore be destined for the synaptic terminal, where it would participate in the breakdown or modification of axonal and synaptic proteins. Other observations indicate that proteins may also be modified or degraded by CANPs in axons (Nixon, 1983). Posttranslational modification of the $145 \mathrm{kDa}$ neurofilament protein by CANP B occurs during axoplasmic transport in vivo (Nixon et al., 1982, 1983, 1986), and neurofilament protein fragments have been observed in axons that are similar to ones generated by CANP in vitro (Schlaepfer et al., 1985). In this regard, we recently showed that a substantial proportion of the newly synthesized neurofilament protein in RGC neurons is deposited into a stationary cytoskeletal network along axons (Nixon et al., 1986). The long halflife of stationary neurofilaments ( $>40 \mathrm{~d}$ ) implies that less than $0.1 \%$ of the potential activity of axonal CANPs could support the local turnover of this network in axons (Nixon et al., 1986).

Differential localization of CANPs may also be relevant to pathological axonal states. The contrast between the high potential activity of axonal CANPs and the low activity necessary to support physiological rates of proteolysis emphasizes the precision with which CANP activity must be regulated, if destruction of the neuron is to be avoided. Indeed, axons exposed to high concentrations of calcium in vitro and in vivo display CANPmediated ultrastructural and molecular changes that resemble the sequence of events during Wallerian degeneration in vivo (Schlaepfer, 1983; Schlaepfer and Micko, 1978; Schlaepfer et al., 1985). Furthermore, neuronal degeneration or cell death induced by certain neurotoxins (Donaldson et al., 1983; Jancsó et al., 1984) and experimental manipulation (O'Brien et al., 1984) are preceded or accompanied by an influx of calcium that may activate CANPs.

In future investigations, examining the separate proteolytic responses of axons and glia to developmental and pathological perturbations may be a particularly fruitful application of the cell biologic approaches used in this study. In addition to providing clucs to the physiological functions of proteinases, these studies may yield useful information about the differential vulnerability of neurons and glia in pathological states.

\section{References}

Banik, N. L., E. L. IIogan, M. G. Jenkins, J. K. McDonald, W. W. McAlhaney, and M. B. Sostek (1983) Purification of a calciumactivated neutral proteinase from bovine brain. Neurochem. Res. 8 : 1389-1405.

Barondes, S. H. (1974) Synaptic macromolecules: Identification and metabolism. Annu. Rev. Biochem. 43: 147-168.

Barth, R., and J. S. Elce (1981) Immunofluorescent localization of a $\mathrm{Ca}^{2+}$-dependent neutral proteinase in hamster muscle. J. Am. Physiol. 240: E493-E498.

Baudry, M., M. C. Bundman, E. K. Smith, and G. S. Lynch (1981) Micromolar calcium stimulates proteolysis and glutamate binding in rat brain synaptic membranes. Science 212: 937-938.

Brown, B. A., R. A. Nixon, P. Strocchi, and C. A. Marotta (1981) Characterization and comparison of neurofilament proteins from rat and mouse CNS. J. Neurochem. 36: 143-153.

Brown, B. A., R. E. Majocha, D. M. Staton, and C. A. Marotta (1983a) Axonal polypeptides cross-reactive with antibodies to neurofilament proteins. J. Neurochem. 40: 299-308.

Brown, B. A., R. A. Nixon, and C. A. Marotta (1983b) Posttranslational processing of $\alpha$-tubulin during axoplasmic transport in CNS axons. J. Cell Biol. 94: 159-164.

Busch, W. A., M. H. Stromer, D. E. Goll, and A. Suzuki (1972) $\mathrm{Ca}^{2+}$ 
specific removal of $Z$ lines from rabbit skeletal muscle. J. Cell Biol. 52: 367-381.

Chiu, F.-C., and W. T. Norton (1982) Bulk preparation of CNS cytoskeleton and the separation of individual neurofilament proteins by gel filtration: Dye-binding characteristics and amino acid compositions. J. Neurochem. 39: 1252-1260.

Dahl, D., and A. Bignami (1973) Immunochemical and immunofluorescence studies of the glial fibrillary acidic protein in vertebrates. Brain Res. 61: 279-293.

Dayton, W. R., and J. V. Schollmeyer (1981) Immunocytochemical localization of a calcium-activated protease in skeletal muscle cells. Exp. Cell Res. 136: 423-433.

Dayton, W. R., J. V. Schollmeyer, R. A. Lepley, and L. R. Cortes (1981) A calcium-activated protease possibly involved in myofibrillar protein turnover. Biochim. Biophys. Acta 659: 48-61.

Donaldson, P. L., I. R. Duce, and P. N. R. Usherwood (1983) Calcium accumulation precedes the degenerative effects of $\mathrm{L}$-glutamate on locust muscle fibres. Brain Res. 274: 261-265.

Glenney, J. R., Jr., P. Glenney, M. Osborn, and K. Weber (1982a) An F-actin- and calmodulin-binding protein from isolated intestinal brush borders has a morphology related to spectrin. Cell 28: 843-854.

Glenney, J. R., Jr., P. Glenney, and K. Weber (1982b) Erythroid spectrin, brain fodrin, and intestinal brush border proteins (TW-260/ 240) are related molecules containing a common calmodulin-binding subunit bound to a variant cell type-specific subunit. Proc. Natl. Acad. Sci. USA 79: 4002-4005.

Goodman, S. R., and I. S. Zagon (1984) Brain spectrin: A review. Brain Res. Bull. 13: 813-832.

Goodman, S. R., I. S. Zagon, C. F. Whitfield, L. A. Casoria, S. B. Shohet, S. E. Bernstein, P. J. McLaughlin, and T. L. Laskiewicz (1984) A spectrin-like protein from mouse brain membrane: Phosphorylation of the 235,000-dalton subunit. Am. J. Physiol. 247 (Cell Physiol. 16): C61-C73.

Ishiura, S. (1981) Calcium-dependent proteolysis in living cells. Life Sci. 29: 1079-1087.

Ishizaki, Y., T. Tashiro, and M. Kurokawa (1983) A calcium-activated protease which preferentially degrades the $160 \mathrm{kDa}$ component of the neurofilament triplet. Eur. J. Biochem. 131: 41-45.

Jancsó, G., S. Karcsú, E. Király, A. Szebeni, L. Tóth, E. Bácsy, F. Joó, and A. Párducz (1984) Neurotoxin induced nerve cell degeneration: Possible involvement of calcium. Brain Res. 295: 211-216.

Kishimoto, A., N. Kajikawa, H. Tabuchi, M. Shiota, and Y. Nishizuka (1981) Calcium-dependent neutral proteases, widespread occurrence of a species of protease active at lower concentrations of calcium. $J$. Biochem. 90: 889-892.

Koenig, E., and E. Repasky (1985) A regional analysis of $\alpha$-spectrin in the isolated Mauthner neuron and in isolated axons of the goldfish and rabbit. J. Neurosci. 5: 705-714.

Lasek, R. J., and P. N. Hoffman (1976) The neuronal cytoskeleton, axonal transport, and axonal growth. In Cell Motility, Vol. 3, R. Goldman, T. Pollard, and J. Rosenbaum, eds., pp. 1021-1049, Cold Spring Harbor Laboratory, NY.

Levine, J., and M. Willard (1981) Fodrin: Axonally transported polypeptides associated with the internal periphery of many cells. J. Cell Biol. 90: 631-643.

Malik, M. N., M. D. Fenko, K. Iqbal, and H. M. Wisniewski (1983) Purification and characterization of two forms of $\mathrm{Ca}^{2+}$-activated neutral protease from calf brain. J. Biol. Chem. 258: 8955-8962.

Murachi, T. (1983) Intracellular $\mathrm{Ca}^{2+}$-protease and its inhibitor protein: Calpain and calpastatin. In Calcium and Cell Function, Vol. 4, W. Y. Cheung, ed., pp. 377-419, Academic, New York.

Murray, N., and A. J. Steck (1984) Impulse conduction regulates myelin basic protein phosphorylation in rat optic nerve. J. Neurochem. 43: $243-248$.

Nelson, W. J., and P. Traub (1982) Purification and further characterization of the $\mathrm{Ca}^{2+}$-activated proteinase specific for the intermediate filament proteins vimentin and desmin. J. Biol. Chem. 257: 5544-5553.
Nixon, R. A. (1980) Protein degradation in the mouse visual system I. Degradation of axonally transported and retinal proteins. Brain Res. 200: 69-83.

Nixon, R. A. (1983) Proteolysis of neurofilaments. In Neurofilaments, C. A. Marotta, ed., pp. 117-154, U. Minnesota P., Minneapolis.

Nixon, R. A., B. A. Brown, and C. A. Marotta (1982) Posttranslational modification of a neurofilament protein during axoplasmic transport: Implications for regional specialization of CNS axons. J. Cell Biol. 94: 150-158.

Nixon, R. A., B. A. Brown, and C. A. Marotta (1983) Limited proteolytic modification of a neurofilament protein involves a proteinase activated by endogenous levels of calcium. Brain Res. 275:384-388.

Nixon, R. A., S. E. Lewis, and C. A. Marotta (1985a) In vivo phosphorylation of neurofilament proteins in retinal ganglion cell (RGC) neurons. J. Neurochem. 44: S60.

Nixon, R. A., K. B. Logvinenko, and W. H. Fisher (1985b) Evidence for a stationary non-uniform network of neurofilaments along retinal ganglion cell axons. Ann. NY Acad. Sci. 455: 797-799.

Nixon, R. A., R. Quackenbush, and A. Vitto (1986) Multiple calciumactivated neutral proteinases (CANP) in mouse retinal ganglion cell neurons: Specificities for endogenous neuronal substrates and comparison to purified brain CANP. J. Neurosci. 6: 1252-1263.

O'Brien, R. A. D., A. J. C. Ostberg, and C. Vrbova (1984) Protease inhibitors reduce the loss of nerve terminals induced by activity and calcium in developing rat soleus muscles in vitro. Neuroscience 12: 637-646.

O'Connell, M. A., and N. I. Swislocki (1983) Spectrin phosphorylation in senescent rat erythrocytes. Mech. Ageing Dev. 22: 51-70.

Pant, H. C., P. E. Gallant, R. Gould, and H. Gainer (1982) Distribution of calcium-activated protease activity and endogenous substrates in the squid nervous system. J. Neurosci. 2: 1578-1587.

Reddy, M. K., J. D. Etlinger, M. Rabinowitz, D. A. Fischman, and R. Zak (1975) Removal of Z-lines and $\alpha$-actinin from isolated myofibrils by a calcium-activated neutral protease. J. Biol. Chem. 250: 4278-4284.

Repasky, E. A., B. L. Granger, and E. Lazarides (1982) Widespread occurrence of avian spectrin in nonerythroid cells. Cell 29:821-833.

Roots, B. I. (1983) Neurofilament accumulation induced in synapses by leupeptin. Science 221: 971-972.

Sandberg, M., A. Hamberger, I. Jacobson, and J.-O. Karlsson (1980) Role of calcium ions in the formation and release of low-molecularweight substances from optic nerve terminals. Neurochem. Res. 5: 1185-1198.

Sato, S., and T. Miyatake (1983) Degradation of myelin basic protein and myelin-associated glycoprotein by calcium-activated neutral protease like enzyme. J. Neurochem. 41: S46.

Schlaepfer, W. W. (1983) Neurofilaments of mammalian peripheral nerve. In Neurofilaments, C. A. Marotta, ed., pp. 57-85, U. Minnesota P., Minneapolis.

Schlaepfer, W. W., and S. Micko (1978) Chemical and structural changes of neurofilaments in transected rat sciatic nerve. J. Cell Biol. 78: 369378.

Schlaepfer, W. W., C. Lee, V. M.-Y. Lee, and U.-J. P. Zimmerman (1985) An immunoblot study of neurofilament degradation in situ and during calcium-activated proteolysis. J. Neurochem. 44: 502509.

Siman, R., M. Baudry, and G. Lynch (1984) Brain fodrin: Substrate for calpain I, an endogenous calcium-activated protease. Proc. Natl. Acad. Sci. USA 81: 3572-3576.

Tennekoon, G. I., S. R. Cohen, D. L. Price, and G. M. McKhann (1977) Myelinogenesis in optic nerve: A morphological, autoradiographic, and biochemical analysis. J. Cell Biol. 72: 604-616.

Zagon, I. S., P. J. McLaughlin, and S. R. Goodman (1984) Localization of spectrin in mammalian brain. J. Neurosci. 4: 3089-3100.

Zimmerman, U.-J.P., and W. W. Schlaepfer (1984) Multiple forms of $\mathrm{Ca}$-activated protease from rat brain and muscle. J. Biol. Chem. 259: 3210-3218. 